\title{
Effect of Moisture Conservation Methods and Plant Density on the Productivity of Two Maize (Zea mays L.) Varieties under Semi-Arid Tropics of Hamelmalo, Eritrea
}

\author{
Shimendi Gde Okbagabir ${ }^{1}$, N. N. Angiras ${ }^{1}$, Biniam Mesfin Ghebreslassie ${ }^{2^{*}}$ \\ ${ }^{1}$ Department of Agronomy, Hamelmalo Agricultural College, Keren, Eritrea \\ ${ }^{2}$ Deprtment of Horticulture, Jomo Kenyatta University of Agriculture and Technology, Juja, Kenya \\ Email: shimendigde@gmail.com, angirasnsk@gmail.com, ‘bm95913@yahoo.com
}

How to cite this paper: Okbagabir, S.G., Angiras, N.N. and Biniam, M.G. (2017) Effect of Moisture Conservation Methods and Plant Density on the Productivity of Two Maize (Zea mays L.) Varieties under Semi-Arid Tropics of Hamelmalo, Eritrea. American Journal of Plant Sciences, 8, 2839.

http://dx.doi.org/10.4236/ajps.2017.81003

Received: October 18, 2016

Accepted: December 26, 2016

Published: December 29, 2016

Copyright $\odot 2017$ by authors and Scientific Research Publishing Inc. This work is licensed under the Creative Commons Attribution International License (CC BY 4.0).

http://creativecommons.org/licenses/by/4.0/

\begin{abstract}
The productivity of maize in Eritrea in general and under semi-arid tropics of Hamelmalo in particular is low because of moisture stress. The low moisture content is ascribed to the low and erratic distribution of rainfall, high temperature, lack of suitable varieties, and competition by weeds and low soil fertility. To overcome some of these problems, a field experiment was carried out to assess the effect of moisture conservation methods (MCM) and plant density on the productivity of two maize (Zea mays L.) varieties under semi-arid tropics of Hamelmalo, Eritrea. The experiment was conducted in split-split plot design with three MCM viz tied ridge, ridge and furrow and flat-bed in main plots; two maize varieties viz early local and 04sadve hybrid in sub plots and three plant densities by manipulating the plant to plant distance viz 35 $\mathrm{cm}, 25 \mathrm{~cm}$ and $15 \mathrm{~cm}$ at a fixed $75 \mathrm{~cm}$ row spacing in sub-sub plots, each replicated thrice. The experiment was focused in addressing the effective moisture conservation techniques, optimum plant density to each variety thus to improve productivity. The crop experienced $10^{\circ} \mathrm{C}$ to $34.8^{\circ} \mathrm{C}$ minimum and maximum temperature, respectively and received $429.1 \mathrm{~mm}$ total rainfall. The results of the experiment indicated that among all the combinations, 04sadve hybrid variety sown at $75 \mathrm{~cm} \times 25 \mathrm{~cm}$ spacing in ridge and furrow method or at $75 \mathrm{~cm} \times 15 \mathrm{~cm}$ spacing in tied ridge or flat-bed method and early local variety sown at $75 \mathrm{~cm} \times 15 \mathrm{~cm}$ spacing in flat-bed being statistically at par resulted in significantly higher moisture conservation and consequently higher grain yield (4509 $\mathrm{kg} \cdot \mathrm{ha}^{-1}$ ) and higher water use efficiency. It is, therefore, recommended that tied ridge or flat-bed of moisture conservation method at $15 \mathrm{~cm}$ plant spacing and 04sadve is preferable to optimize productivity in Hamelmalo area, Eritrea.
\end{abstract}




\section{Keywords}

Eritrea, Moisture Conservation Methods, Maize Varieties, Water Use Efficiency

\section{Introduction}

Maize (Zea mays L.), also locally known as efun in Eritrea, ranks third after sorghum and pearl millet among summer food grains and fifth among all food grains after sorghum, pear millet, wheat and barley in both area and production. The productivity of this crop in Africa in general and Eritrea in particular is much lower than its average productivity $(4472 \mathrm{~kg} / \mathrm{ha})$ in the world. The low productivity of maize in Eritrea is attributed to the lack of quality seeds of high yielding varieties, moisture stress due to low and erratic rainfall, high temperature, low soil fertility, competition by weeds, inappropriate tillage and sowing system, lack of nutrient supplying capacity of the soil and timely non availability of the fertilizer to the farmers [1]. In addition to these, the degraded land with limited soil moisture availability at critical stages of crop growth is other major constraints of low productivity. Among these moisture stresses due to low and erratic rainfall, lack of appropriate methods of soil moisture conservation, lack of adaptable varieties to moisture stress and their optimum population density are the dominant in reducing its average productivity. In Eritrea, maize is produced in very marginal areas like highland and thus the production is not sufficient to meet the aggressive demand by the consumers.

Maize contains both corneous and soft starch 61 percent with high content of essential amino acid. It is kernel contains 13.5 percent moisture, 10 percent crude protein, 4.3 percent oil and 70.3 percent carbohydrate [2]. It has the highest production potential among the cultivated field crops and is known as "queen of cereals". Its uses as main source of food and for local drink as well as animal feed make it a multipurpose crop [3]. The grain of this crop is an excellent source of human diet in the form of bread, roasted and local drink. The oil content of hybrid corn ranges from 3.5 to 6 percent with average of 4.5 percent [4]. Stover and grain are used as animal feed and have wide ranges of industrial applications in pharmaceuticals, cosmetics and textile industries in developed countries. It has a great potential for efficient input use, crop diversification, foreign exchange earnings and greater employment through agro-industries and food security especially popcorn [2].

In Africa it is being grown in an area of 27,114 thousand ha with a production of 435,182 thousand metric tones and average productivity of $1605 \mathrm{~kg} / \mathrm{ha}$ [3] whereas in Eritrea it covers an area of 19,621 ha of land with annual production of 29,053 tones and an average productivity of $1480.7 \mathrm{~kg} / \mathrm{ha}$ [5].

The average annual rainfall in Eritrea is around $450 \mathrm{~mm}$ and is not uniformly distributed indicating moisture stress as one of the major constraints for crop productivity [6]. In order to protect the crop from frequent agricultural drought 
development, efficient rain water conservation methods are necessary for sustainable high yields. Testing, thus, identifying suitable varieties under low moisture concomitant to soil moisture conservation techniques is of paramount importance to improve productivity. Increase in intra-row spacing results in larger leaf area by reducing the competition for space, sunlight and nutrients. Competition among maize plants for light, soil fertility and other environmental factors increases markedly with higher population and vice versa [7]. Therefore, optimum plant population is the pre-requisite for maximum utilization of inputs for higher productivity [8].

The experimental farm of Hamelmalo Agricultural College in Eritrea is part of semi-arid agro ecological zone having average annual rainfall of about $468 \mathrm{~mm}$ with erratic and unreliable distribution which greatly influence the yield of crops [6]. In the absence of effective soil moisture conservation technologies farmers grow maize only in limited areas and have no choice except to grow monoculture of sorghum and pearl millet. No research was conducted on the response of moisture conservation and plant population on the performance of maize varieties in Eritrea. Keeping in view the above factors, thus, a study was conducted to assess the effect of moisture conservation methods and plant density on the productivity of maize under semi-arid conditions.

\section{Materials and Methods}

The field experiment was conducted during summer season, 2014 at the Model Integrated Watershed Management farm area of Hamelmalo Agricultural College (HAC), located in Hamelmalo, Eritrea. The site is located $12 \mathrm{~km}$ North of Keren at latitude of $15^{\circ} 52^{\prime} 21^{\prime \prime} \mathrm{N}$ and longitude of $38^{\circ} 27^{\prime} 42^{\prime \prime} \mathrm{E}$, and at an altitude of $1285 \mathrm{~m}$ above mean sea level. The climate of the area is semi-arid with $429.1 \mathrm{~mm}$ average annual rain fall for the growing season with average annual maximum and minimum temperatures of $34.8^{\circ} \mathrm{C}$ and $10^{\circ} \mathrm{C}$, respectively. The weekly rainfall distribution at Hamelmalo Agricultural College during the experimental period was exceptionally uniform throughout the growing season. Before sowing of the crop a composited representative soil sample was taken from $30 \mathrm{~cm}$ soil. The sample was thoroughly mixed and analyzed for its physico-chemical properties. The soil of the experimental field was sandy loam in texture, alkaline in reaction ( $\mathrm{pH} 8.2)$, very low in organic matter content $(0.27 \%)$, very low in available nitrogen, low in available phosphorus and low in potassium [9].

The experimental field was ploughed with disc plough followed by disc harrow. Weeds and crop residues were removed manually. Field was leveled and surface of plots was configured manually with hoe and shovel depending on the different MCM (Tied ridge, Ridge and furrow and flat-bed) which are allocated to the main plot. To the sub plot two varieties (early local and 04sadve (hybrid) were allocated and three plant spacing $35 \mathrm{~cm}, 25 \mathrm{~cm}$ and $15 \mathrm{~cm}$, respectively with a constant row spacing for $75 \mathrm{~cm}$ was used. The crop was sown on $28^{\text {th }}$ June, 2014 at $5-7 \mathrm{~cm}$ depth by dibbling method with hand tool. The field experiment was conducted in split-split plot design with three replications. Fertilizers 
were applied as per recommendation of National Agricultural Research Institution (NARI) at the rate of $18 \mathrm{~kg} \mathrm{~N}$ and $46 \mathrm{~kg} \mathrm{P} \mathrm{P}_{2} \mathrm{O}_{5}$ through $100 \mathrm{~kg} \cdot \mathrm{ha}^{-1} \mathrm{DAP}$ at the time of sowing. Top dressing of $23 \mathrm{~kg} \mathrm{~N} / \mathrm{ha}$ from $50 \mathrm{~kg}^{\mathrm{U}} \mathrm{Urea} \mathrm{ha}{ }^{-1}$ was done in two equal splits at 20 and 40 days after sowing (DAS). Three hand weeding were done at 20, 40 and 60 days after sowing (DAS). A uniform application of Malatox at 40 DAS was applied to control minor attack of stem borer and ants. Harvesting was done when the cob husks dried and turned yellowish in colour. Soil moisture content was determined by gravimetric method [10] at 20 days interval from time of sowing up to 100 DAS. Soil samples were taken by tube auger from $15 \mathrm{~cm}$ and $30 \mathrm{~cm}$ soil layers from the net plot area and were weighed and oven dried at $105^{\circ} \mathrm{C}$ till constant weight was obtained. Percent soil moisture content on dry weight basis was calculated following the formula:

$$
\text { Soil moisture }(\%)=\frac{W_{1}-W_{2}}{W_{2}} \times 100
$$

where $W_{1}=$ Fresh weight of soil before oven dry, and $W_{2}=$ weight of oven dried soil.

Water used $(\mathrm{mm})$ by the crop was taken as the evapotranspiration of the crop (ETc). Soil moisture content of the sandy loam soils at field capacity, permanent wilting point and available water ranged between $10 \%-18 \%, 4 \%-8 \%$ and $6 \%$ $10 \%$, respectively $[11]$.

The amount of water $(\mathrm{mm})$ lost through evapotranspiration from the soil and crop was calculated as follows:

Evapotranspiration of the crop $($ ETc $)(\mathrm{mm})=$ Evapotranspiration $($ ETo $) \times \mathrm{Kc}$ where ETo is evaporation recorded using the US open pan evaporimeter and Kc is the crop coefficient given by FAO [12]. The water used in evapotranspiration, and for metabolic activities was calculated by multiplying the ETo with the crop coefficient value of 1.2 [12]. The water used Efficiency was calculated following the formula given by [13] as follows:

$$
\text { WUE } \frac{\mathrm{kg}}{\mathrm{ha}} / \mathrm{mm}=\frac{\text { Grain yield } \mathrm{kg} / \mathrm{ha}}{\text { Water used }(\mathrm{mm})} \text {. }
$$

The data on yield attributes, biological yield, grain yield and water use efficiency after harvest of the crop were collected. The data obtained from all the measured parameters of the experiment under various treatments were subjected to statistical analysis by using the GENSTAT software ( $4^{\text {th }}$ ed) and IBM SPSS statistical package version 20. The treatment means were compared with LSD at 5 per cent level of significance ( $95 \%$ confidence limit) for the analysis of variance.

\section{Results and Discussions}

\subsection{Effect on Soil Moisture Contents}

The critical perusal of the data in (Table 1) revealed that moisture conservation methods significantly influenced the soil moisture content in both soil layers at all the observation stages except at $15 \mathrm{~cm}$ at 20 DAS and 60 DAS. Among the 
Table 1. Effect of treatments on periodic soil moisture content (\%) at different soil depth.

\begin{tabular}{|c|c|c|c|c|c|c|c|c|c|c|}
\hline \multirow{4}{*}{ Treatments } & \multicolumn{10}{|c|}{ Moisture \% } \\
\hline & \multicolumn{2}{|c|}{ At sowing } & \multicolumn{2}{|c|}{20 DAS } & \multicolumn{2}{|c|}{40 DAS } & \multicolumn{2}{|c|}{60 DAS } & \multicolumn{2}{|c|}{80 DAS } \\
\hline & \multicolumn{10}{|c|}{ Depth $(\mathrm{cm})$} \\
\hline & $15 \mathrm{~cm}$ & $30 \mathrm{~cm}$ & $15 \mathrm{~cm}$ & $30 \mathrm{~cm}$ & $15 \mathrm{~cm}$ & $30 \mathrm{~cm}$ & $15 \mathrm{~cm}$ & $30 \mathrm{~cm}$ & $15 \mathrm{~cm}$ & $30 \mathrm{~cm}$ \\
\hline \multicolumn{11}{|c|}{$\mathrm{MCM}$} \\
\hline Tied Ridge & $10.3 \mathrm{a}$ & $9.4 \mathrm{a}$ & $12.7 \mathrm{a}$ & $14.2 \mathrm{a}$ & $11.2 \mathrm{a}$ & $13.1 \mathrm{a}$ & $12.3 \mathrm{a}$ & $11.8 \mathrm{a}$ & $5.8 \mathrm{a}$ & $5.9 \mathrm{a}$ \\
\hline Ridge and Furrow & $9 \mathrm{~b}$ & $6.2 \mathrm{~b}$ & $11.0 \mathrm{a}$ & $7.4 \mathrm{~b}$ & $9 \mathrm{~b}$ & $9.2 \mathrm{c}$ & $9.7 \mathrm{a}$ & $9.2 \mathrm{~b}$ & $4 \mathrm{~b}$ & $5.3 \mathrm{~b}$ \\
\hline Flat bed & $7.5 \mathrm{c}$ & $7.5 \mathrm{~b}$ & $11.5 \mathrm{a}$ & $10.5 b$ & $10.8 \mathrm{a}$ & $10.8 \mathrm{~b}$ & $11.1 \mathrm{a}$ & $9 . b$ & $4.1 \mathrm{~b}$ & $4.5 \mathrm{c}$ \\
\hline $\mathrm{CV} \%$ & 3.3 & 9.9 & 11.7 & 12.8 & 5.8 & 2.7 & 8.3 & 3.2 & 5.5 & 0.001 \\
\hline LSD (0.05) & 0.68 & 1.74 & NS & 3.11 & 1.36 & 0.69 & NS & 0.73 & 0.57 & 0.002 \\
\hline \multicolumn{11}{|c|}{ Varieties } \\
\hline Early local & $9.05 a$ & $7.44 a$ & $11.96 \mathrm{a}$ & $11.15 \mathrm{a}$ & $10.25 \mathrm{a}$ & $11.19 \mathrm{a}$ & $10.82 \mathrm{a}$ & $10.54 \mathrm{a}$ & $4.44 \mathrm{a}$ & $4.95 \mathrm{~b}$ \\
\hline 04sadve & $8.81 \mathrm{a}$ & $7.98 \mathrm{a}$ & $11.53 \mathrm{a}$ & $11.15 \mathrm{a}$ & $10.45 a$ & $10.85 a$ & $11.25 \mathrm{a}$ & $9.63 \mathrm{~b}$ & $4.78 \mathrm{a}$ & $5.53 \mathrm{a}$ \\
\hline $\mathrm{CV} \%$ & 5.3 & 12.2 & 15.4 & 8.6 & 5 & 9.7 & 5.5 & 9.3 & 12.3 & 0.2 \\
\hline LSD (0.05) & NS & NS & NS & NS & NS & NS & NS & 0.42 & NS & 0.0015 \\
\hline \multicolumn{11}{|c|}{ Plant-plant spacing $(\mathrm{cm})$} \\
\hline $35 \mathrm{~cm}$ & $9.4 \mathrm{a}$ & $8.0 \mathrm{a}$ & $12.1 \mathrm{a}$ & $10.8 \mathrm{a}$ & $11.1 \mathrm{a}$ & $11.4 \mathrm{a}$ & $11.7 \mathrm{a}$ & $10.63 a$ & $5.0 \mathrm{a}$ & $5.8 \mathrm{a}$ \\
\hline $25 \mathrm{~cm}$ & $8.9 \mathrm{a}$ & $7.5 \mathrm{a}$ & $11.6 \mathrm{a}$ & $10.4 \mathrm{a}$ & $10.3 \mathrm{~b}$ & $11.1 \mathrm{a}$ & $11.1 \mathrm{~b}$ & $10.2 \mathrm{a}$ & $4.6 \mathrm{~b}$ & $5.20 \mathrm{~b}$ \\
\hline $15 \mathrm{~cm}$ & $8.4 \mathrm{~b}$ & $7.6 \mathrm{a}$ & $11.5 \mathrm{a}$ & $10.8 \mathrm{a}$ & $9.6 c$ & $10.5 \mathrm{a}$ & $10.4 \mathrm{c}$ & $9.4 \mathrm{~b}$ & $4.2 \mathrm{c}$ & $4.8 \mathrm{c}$ \\
\hline CV\% & 5.3 & 12.2 & 15.4 & 8.6 & 5 & 9.7 & 5.5 & 9.3 & 12.3 & 0.2 \\
\hline $\operatorname{LSD}(0.05)$ & 0.63 & NS & NS & NS & 0.36 & NS & 0.42 & 0.64 & 0.39 & 0.007 \\
\hline
\end{tabular}

Means with the same letters under the same column are not significant $(\mathrm{P}>0.05)$ different using Duncan Multiple Range Test $(\mathrm{DMRT})$. MCM = Moisture conservation method; DAS = days after sowing.

moisture conservation methods, tied ridge being effective in checking runoff losses and increasing infiltration of water resulted in significantly highest soil moisture content in both the layers of the soil at all the stages of the observation. At $15 \mathrm{~cm}$ soil layer during sowing and at $30 \mathrm{~cm}$ soil layer at harvesting flat-bed method was inferior to ridge and furrow method and at 40 DAS flat-bed method and ridge and furrow method were inferior in moisture conservation. However, it was statistically at par with ridge and furrow methods at $30 \mathrm{~cm}$ soil layer at sowing and 60 DAS and at $15 \mathrm{~cm}$ soil layer at harvesting (80 DAS). [14] have also revealed that tied ridge was effective in reducing runoff and increase soil water storage, ultimately increasing the yield of the crop.

Varieties did not significantly influence the moisture conservation in two soil layers at all the stages of observation except in $30 \mathrm{~cm}$ layer at 60 DAS and 80 DAS. The significantly higher soil moisture content at $30 \mathrm{~cm}$ soil layer in the early local grown plots at 60 DAS may be attributed to density of its lesser roots in the $30 \mathrm{~cm}$ soil layers which could utilize less moisture from the deeper layer as compared to hybrid variety. Similar, observations were made by [15]. 
The variation in plant spacing did not significantly influence the soil moisture content at sowing and 20 DAS because of the less variation in the canopy formation due to plant spacing at initial stages of the growth. But at 40 and 60 stages of observation, plant spacing influenced the moisture content significantly in both the layer of the soil except in $30 \mathrm{~cm}$ soil layer at 40 DAS. Increasing in plant density by decreasing in plant to plant spacing from $35 \mathrm{~cm}$ to $15 \mathrm{~cm}$ decreased the moisture content in both the soil layers because of utilization of moisture by higher plant population.

\subsection{Interaction Effects of MCM and Varieties}

Moisture conservation methods and varieties interacted significantly influencing the soil moisture content (SMC) in $30 \mathrm{~cm}$ layer at harvest (80 DAS) stage of observation (Table 2). Combination of tied ridge orridgeand furrow with 04sadve hybrid variety resulted in significantly higher soil moisture content in both the soil layers as compared to local variety. Among all the combination of MCM and variety, tied ridge and 04sadve hybrid variety resulted in significantly highest SMC in both layer followed by combination of ridge and furrow and 04sadve. These findings are inconformity with those of [15] who reported that tied ridge decreased surface runoff from the field and increased retention of rain water with in the soil.

\subsection{Effect on Yield Attributes}

\subsubsection{Cob Length}

The data presented in (Table 3) indicated that MCM, varieties and plant spacing did not significantly influence the cob length but numerically tied ridge methods produced longest cob due to more retention and infiltration of rain water. 04sadve hybrid variety was numerically superior in mean cob length $(14.88 \mathrm{~cm})$ over early local variety. According to [16] maximum cob length was obtained

Table 2. Interaction effect of MCM and varieties at harvest (80 DAS) on moisture content (\%).

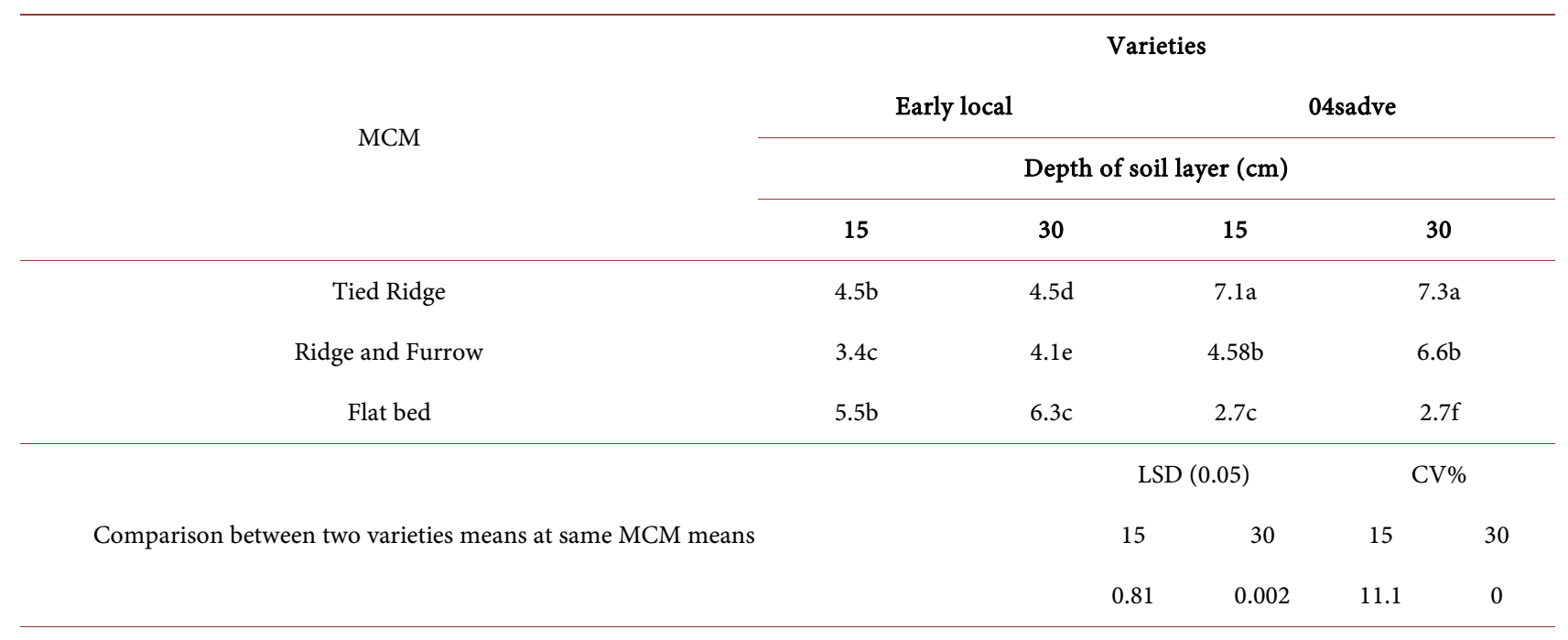

Comparison between two varieties means at same or different MCM means 
Table 3. Effect of different treatments on the yield and yield attributes of maize.

\begin{tabular}{|c|c|c|c|c|c|c|c|}
\hline Treatments & $\begin{array}{l}\text { No. of cobs per } \\
\text { plants }\end{array}$ & $\begin{array}{l}\text { Cob Length } \\
\text { (cm) }\end{array}$ & $\begin{array}{l}\text { No. of rows } \\
\text { per cob }\end{array}$ & $\begin{array}{l}1000 \text { grain } \\
\text { Weight (g) }\end{array}$ & $\begin{array}{c}\text { Biological yield } \\
\left(\mathrm{kg} \cdot \mathrm{ha}^{-1}\right)\end{array}$ & $\begin{array}{c}\text { Grain yield in } \\
\left(\mathrm{kg} \cdot \mathrm{ha}^{-1}\right)\end{array}$ & $\begin{array}{c}\text { WUE } \\
(\mathrm{kg} / \mathrm{mm})\end{array}$ \\
\hline \multicolumn{8}{|c|}{ MCM } \\
\hline Tied Ridge & $1.48 \mathrm{a}$ & $14.9 \mathrm{a}$ & $12.32 \mathrm{a}$ & $258.2 \mathrm{a}$ & $7943 a$ & $3284 a$ & $5.66 \mathrm{a}$ \\
\hline Ridge and Furrow & $1.2 \mathrm{a}$ & $13.6 \mathrm{a}$ & $10.5 b$ & $232.3 \mathrm{a}$ & $6764 a$ & $2805 a$ & $4.83 \mathrm{~b}$ \\
\hline Flat bed & $1.3 \mathrm{a}$ & $14.5 \mathrm{a}$ & $11.2 \mathrm{ab}$ & $253.7 \mathrm{a}$ & $8123 a$ & $3280 a$ & $5.65 a$ \\
\hline CV\% & 8.7 & 4.5 & 4.5 & 3.7 & 9.4 & 5.9 & 5.9 \\
\hline LSD (0.05) & NS & NS & 1.147 & NS & NS & NS & 0.73 \\
\hline \multicolumn{8}{|c|}{ Varieties } \\
\hline Early local & $1.31 \mathrm{a}$ & $13.7 \mathrm{a}$ & $9.9 \mathrm{~b}$ & $244.8 \mathrm{a}$ & $6790 a$ & $2815 b$ & $4.85 \mathrm{~b}$ \\
\hline 04sadve & $1.3 \mathrm{a}$ & $14.9 \mathrm{a}$ & $12.8 \mathrm{a}$ & $251.3 \mathrm{a}$ & $8430 a$ & $3432 a$ & $5.91 \mathrm{a}$ \\
\hline CV\% & 15.8 & 10.9 & 9.20 & 14.0 & 21.4 & 20.1 & 20.1 \\
\hline $\operatorname{LSD}(0.05)$ & NS & NS & 1.221 & NS & NS & 234.2 & 0.81 \\
\hline \multicolumn{8}{|c|}{ Plant spacing $(\mathrm{cm})$} \\
\hline 35 & $1.4 \mathrm{a}$ & $14.1 \mathrm{a}$ & $11 \mathrm{a}$ & $255.4 \mathrm{a}$ & $6758 b$ & $2800 c$ & $4.83 \mathrm{~b}$ \\
\hline 25 & $1.4 \mathrm{a}$ & $14.5 \mathrm{a}$ & $11.51 \mathrm{a}$ & $236 \mathrm{a}$ & $7330 \mathrm{~b}$ & $3073 b$ & $5.3 \mathrm{~b}$ \\
\hline 15 & $1.2 \mathrm{~b}$ & $14.2 \mathrm{a}$ & $11.5 \mathrm{a}$ & $252.7 \mathrm{a}$ & $8742 a$ & $3496 a$ & $6.03 a$ \\
\hline CV\% & 15.8 & 10.9 & 9.2 & 3.3 & 21.4 & 20.1 & 20.1 \\
\hline LSD (0.05) & 0.1432 & NS & NS & NS & 1122.8 & 215 & 0.74 \\
\hline
\end{tabular}

Means with the same letters under the same column are not significant $(\mathrm{P}>0.05)$ different using Duncan Multiple Range Test $($ DMRT $)$. WUE $=$ water use efficiency.

from hybrid variety Azam and minimum from Pahari. This is attributed due to hybrid varieties have very deep root and vigorous vegetative growth where they can extract more moisture from the deep root soil. Plant spacing did not significantly influence the cob length but there was a trend of cob length increase using $25 \mathrm{~cm}$ plant spacing while reduction at $15 \mathrm{~cm}$ spacing ascribed to highest plant density (Table 3). The same scenario was reported by [17] cited in [18] where decrease in ear (cob) length as a result of increased in plant population.

\subsubsection{Number of Cobs per Plant}

The data on the effect of different treatments on number of cobs per plant presented in (Table 3) indicated that moisture conservation method and varieties did not significantly influence the number of cobs per plant, but numerically highest number of cobs per plant (1.48) was obtained in tied ridge. This numerical increase could be accredited to more available moisture content in tied ridge MCM (Table 1) followed by flat-bed method. The data further shown that 25 and $35 \mathrm{~cm}$ plant spacing being at par produced significantly higher cob number over $15 \mathrm{~cm}$ plant spacing due to lower plant population leading to less mutual competition for available nutrients, moisture, space and light. This finding is in agreement with [19] cited [20] who also reported higher numbers of cobs and grain yield as a result of lower plant density. 


\subsubsection{Number of Rows per Cob}

The data in (Table 3 ) indicated that while MCM and varieties significantly influenced the number of rows per cob, but plant spacing did not significantly influenced the number of rows per cob. Among the MCM tied ridge and flat-bed methods being statistically equal produced significantly higher number rows per cob because of higher moisture contents conserved by the two methods (Table 1) which produced better growth and development of the crop. The results are partly in agreement with those of [21] who reported that rows per cob were increased at certain levels of moisture due to increase in cob size. Similar to this finding [22] reported the superiority of hybrid maize over composite cultivarsin increasing number of rows per cob due to its uniformity in flowering and disease resistance and genetic potential.

\subsubsection{Thousand Grain Weight (g)}

Thousand grain weight was not influenced significantly by the treatments understudy (Table 3). Among the MCM ridge followed by flat-bed method produced numerically higher 1000 grain weight. Hybrid 04sadve variety produced numerically higher 1000 grain weight over the local variety. Among the plant spacings, $35 \mathrm{~cm}$ plant to plant spacing produced numerically highest test weight as compared to the others. These finding are in accordance to those of [23] who reported that increasing crop density reduced the thousand grain weight.

\subsubsection{Interaction Effect of MCM and Varieties on Number of Cob per Plant}

MCM and varieties interacted significantly to influence the number of cobs per plant (Figure 1). The data presented indicated that irrespective of MCM, 04sadve hybrid variety resulted in significantly higher number of cobs per plant than early local variety due to its genetic superiority. Among all the combination of MCM and varieties, tied ridge and 04sadve hybrid variety being statistically at par with tied ridge and early local variety and flat-bed method with early local resulted in significantly higher number of cob per plant due to higher moisture

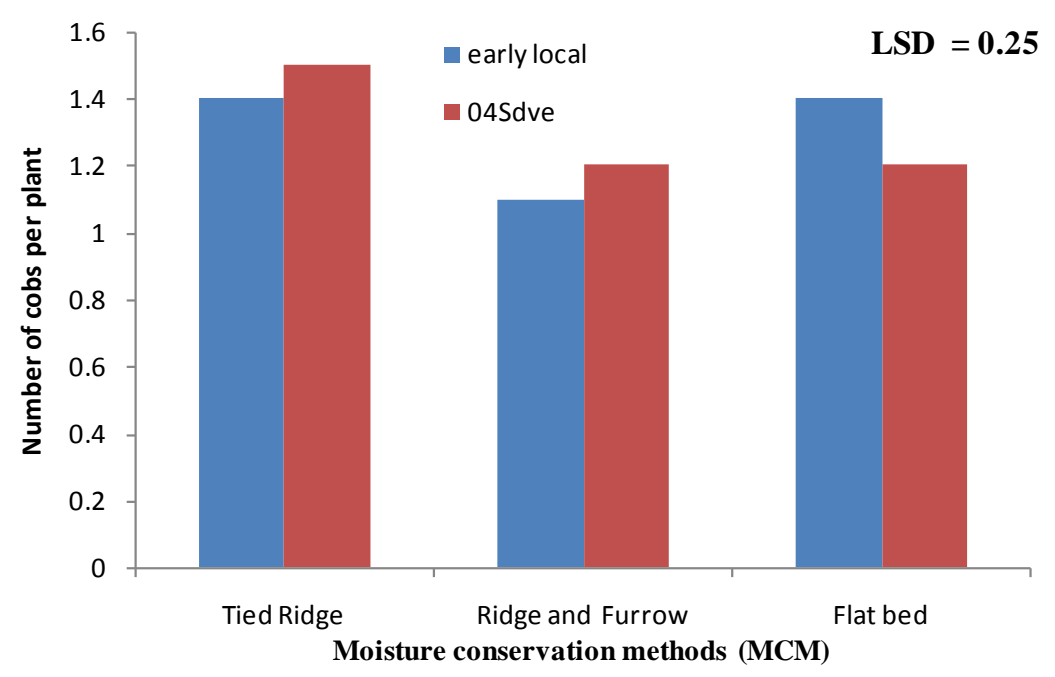

Figure 1. Interaction effect of MCM and varieties on number of cobs per plant. 
conservation by these methods (Table 1) and efficient utilization of conserved moisture by both the varieties.

\subsection{Effect on Biological and Grain Yield}

\subsubsection{Biological Yield (kg.ha-1)}

Moisture conservation methods did not significantly influence the biological yield but numerically flat-bed methods produced highest biological yield followed by tied ridge methods due to higher soil moisture content (Table 1). There was no significant variation among the studied varieties, but a trend of biological yield increase was noted from 04sadve hybrid compared to the early local. The higher biological yield from 04 sadve variety may be attributed to higher density of roots in the deeper layer which could utilize high moisture from the deeper layer. The mean value with respect to leaf area of hybrid variety 9022-13 $\left(673.2 \mathrm{~cm}^{2}\right)$ indicated that the variety was superior to other varieties tested [24]. The plant spacing significantly influenced the biological yield. Significantly highest biological yield was obtained with the highest plant density of $15 \mathrm{cmplant}$ spacing. The higher plant population utilized the high moisture content from the deeper layers and intercepted more photosynthetically active radiation for higher photosynthetic activity. [25] found vigorous vegetative growth, greater dry matter accumulation and fewer photos assimilates partitioning from vegetative to reproductive phase as the main indicators of higher biological yield.

\subsubsection{Grain Yield (kg·ha-1)}

The grain yield was not significantly influenced by the MCM due to uniform distribution of rains and the moisture conserved by MCM at almost all the critical stages (Table 3). However, tied ridge produced numerically highest grain yield $(3284 \mathrm{~kg} / \mathrm{ha}$ ). Whereas the hybrid variety 04 sadve produced significantly highest grain yield over early local variety because of its genetic potential which helped it to utilize available moisture, nutrient and light more efficiently and thus produced significantly higher number of grain rows per cob, numerically higher cob length and 1000 grain weight (Table 3). Increasing plant density by decreasing plant spacing from $35 \mathrm{~cm}$ to $15 \mathrm{~cm}$ resulted in significant increase in grain yield of maize due to sufficient available moisture provided by uniform distribution of rain and moisture conserved by different methods. This is similar to the findings of [19] cited in [20] who also reported higher grain yield with higher plant density obtained following narrow spacing.

\subsubsection{Interaction Effect of MCM, Varieties and Plant Spacing on Grain Yield (kg.ha-1)}

Moisture conservation methods, varieties and plant spacing significantly influenced the grain yield (Figure 2). A perusal of the data indicated that combination of 04sadve hybrid variety sown at $25 \mathrm{~cm}$ spacing in ridge and furrow method resulted in significanly higher grain yield $(4509 \mathrm{~kg} / \mathrm{ha}$ ) followed by a combination of 04sadve variety sown at $15 \mathrm{~cm}$ plant spacing in tied ridge (4023 $\mathrm{kg} / \mathrm{ha}$ ) and both the varieties sown at $15 \mathrm{~cm}$ spacing in flat-bed method (4057 $\mathrm{kg} / \mathrm{ha}$ ) which were statistically at par. 


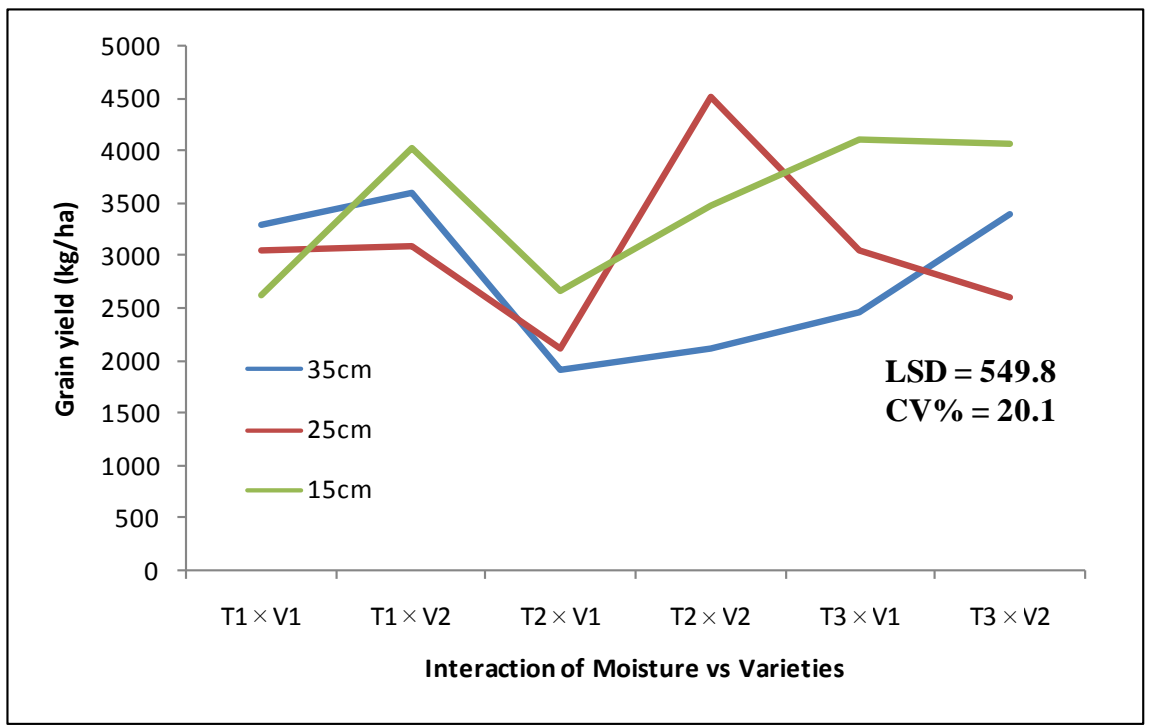

Figure 2. Interaction effect of MCM and Varieties and Plant spacing on grain yield $(\mathrm{kg} / \mathrm{ha})$ of maize. Where: $\mathrm{T} 1$ = tied ridge, $\mathrm{T} 2$ = ridge and furrow, $\mathrm{T} 3$ = flat-bed, $\mathrm{V} 1$ = early local variety and V2 04sadve variety.

\subsection{Effect on Water Use Efficiency (WUE)}

The WUE based upon grain yield was significantly influenced by moisture conservation methods, varieties and plant spacing (Table 3). Among MCMs, flatbed and tied ridge being statistically at par resulted in significantly higher WUE as compared to ridge and furrow methods. Tied ridge and flat-bed method gave WUE of 5.66 and $5.65 \mathrm{~kg} / \mathrm{ha} / \mathrm{mm}$, respectively. The higher WUE due to their methods is attributed to their efficiency in conserving more rain water (Table 1) which helped in increasing the grain yield. The significantly higher WUE of 04sadve hybrid variety over early local may be attributed to its vigorous vegetative growth, greater dry matter accumulation and more photo assimilates partitioning from vegetative to reproductive phase due to efficient use of resources. Similarly, in 2013 they were tested in the post graduate research growth and yielded $\mathrm{kg} / \mathrm{ha}$ of $04 \mathrm{sadve}$ greater than early local [26]. Moreover, according to [27] improved crop growth increases the ability of the crop to extract more moisture from the soil. Plant spacing significantly influenced the WUE. Increasing in plant density with decrease in plant spacing from $35 \mathrm{~cm}$ to $15 \mathrm{~cm}$ numerically increased the WUE but statistically WUE at $15 \mathrm{~cm}$ spacing was at par with $25 \mathrm{~cm}$ spacing. The increase in WUE with increase in plant density could be ascribed to efficient utilization of conserved to moisture by better interaction of photosynthetically active radiation (PAR) reduced evapotranspiration and more translocation of photosynthates to the grain.

\section{Conclusion and Recommendation}

Because of the uniform distribution of rainfall during the experimental year, all the three methods of moisture conservations were found equally effective in influencing grain yield, biological yield and water use efficiency. Hybrid variety 
04sadve was found to be superior to the early local variety. Highest plant density obtained with $75 \mathrm{~cm} \times 15 \mathrm{~cm}$ spacing resulted in significantly higher grain yield, biological yield and water use efficiency. Among all the combinations 04sadve hybrid variety sown at $75 \mathrm{~cm} \times 25 \mathrm{~cm}$ spacing in ridge and furrow method produced significantly higher grain yield (4509 $\mathrm{kg} \cdot \mathrm{ha}^{-1}$ ), although it was statistically at par with combination of 04sadve variety sown at $75 \mathrm{~cm} \times 15 \mathrm{~cm}$ spacing in tied ridge and both varieties sown at $75 \mathrm{~cm} \times 15 \mathrm{~cm}$ spacing in flat-bed method of moisture conservation. It is, therefore, recommended that 04 sadve hybrid variety sown at $75 \mathrm{~cm} \times 25 \mathrm{~cm}$ spacing in ridge and furrow method and 04sadve hybrid variety sown at $75 \mathrm{~cm} \times 15 \mathrm{~cm}$ spacing in tied ridge should be introduced at Hamelmalo and other areas of the country with similar climatic conditions.

\section{Acknowledgements}

The authors wish to thank the Eritrean National Board for Higher Education in general and Hamelmalo Agricultural College (HAC) in particular for funding the research project.

\section{References}

[1] Bisrat, G. and Abraham, M. (2003) Introducing Small-Scale Irrigation Technology in Eritrea: Lessons and Experiences. In: Mehari, T. and Ghebru, B., Ed., Irrigation Development in Eritrea: Potentials and Constraints, Proceedings of the Workshop of the Association of Eritreans in Agricultural Sciences (AEAS) and the Sustainable Land Management Program (SLM) Eritrea, 14-15 August 2003, Asmara.

[2] Martin, J.H., Waldren, R.P. and Stamp, D.L. (2006) Principles of Field Crop Production. Pearson Education, Inc., Upper Saddle River.

[3] FAO (2003) Production Year Book. Vol. 57.

[4] Dudley, J.W. and Lambert, R.J. (1974) Seventy Generations of Selection for Oil and Protein Concentration in the Maize Kernel. In: Dudley, J.W., Ed., Seventy Generations of Selection for Oil and Protein Concentration in Maize, Spec. Pub. Crop Sci. Soc. Am., Madison, 181-212. https://doi.org/10.2135/1974.seventygenerations.c9

[5] MoA (2011) Ministry of Agriculture, National Wise. Annual Report, Asmara.

[6] MoA (2014) Ministry of Agriculture, Zoba Anseba. Annual Report, Keren.

[7] Sharma, T.R. and Adamu, I.M. (1984) The Effects of Plant Population on the Yield and Yield Attributing Characters in Maize (Zea mays L.). Field Crop Abstracts, 38, 34-37.

[8] Trenton, F., Stanger, S. and Joseph, G.L. (2006) Optimum Plant Population of Bacillus thuringiensis and Non Bacillus thuringiensis Corn in Wisconsin. Agronomy Journal, 98, 914-921. https://doi.org/10.2134/agronj2005.0144

[9] Million, T. (2014) Status and Distribution of Macro Nutrients at Hamelmalo Experimental Farm. MSc. Thesis, Submitted to Hamelmalo Agricultural College, Eritrea.

[10] Walter, H.G. (1986) Water Content. In: Klute, A., Ed., Methods of Soil Analysis, Part I, Physical and Mineralogical Methods, 2nd edition. American Society of Agronomy, Inc. and Soil Science Society of America, Inc., Madison, 493-541.

[11] Israelsen, O.W. and Hansen, V.E. (1962) Irrigation Principles and Practices. 3rd Edition, Wiley International Edition, New York.

[12] Allen, R., Pereira, L., Raes, D. and Smith, M. (1998) Crop Evapotranspiration: 
Guidelines for Crop Computing Crop Water Requirements-FAO Irrigation and Drainage Paper 56. 9th Edition, FAO, Rome.

[13] Gregory, P.J. (1988) Plant and Management Factors Affecting the Water Use Efficiency of Dryland Crops. In: Unger, P.W., Sneed, T.V., Jorden, W.R. and Jensen, R., Eds., Challenges in Dryland Agriculture, Texas Agric. Exp. Stn., College Station, 171-175.

[14] Hulugalle, N.R. and Matlon, P.J. (1990) Effect of Rock Bunds and Tied Ridges on Soil Water Content and Soil Properties in Sudan Savannah of Burkina Faso. Tropical Agriculture, 67, 149-153.

[15] Wiyo, K.A., Kasomera, Z.M. and Feyen, J. (2000) Effect of Tied Ridge on Soil Water Status of Maize Crop under Malawi Conditions. Agricultural Water Management, 45, 101-125. https://doi.org/10.1016/S0378-3774(99)00103-1

[16] Esechie, H.A. (1992) Effect of Planting Density on Growth and Yield of Irrigated Maize in the Batinah Coast Region of Oman. The Journal of Agricultural Science, 119, 165-169. https://doi.org/10.1017/S0021859600014076

[17] Hassan, A.A. (2000) Effect of Plant Population Density on Yield and Yield Components of 8 Egyptian Maize Hybrids. Bulletin of Faculty of Agriculture, University of Cairo, 51, 1-16.

[18] Shafi, M., Bakth, J., Ali, J., Khan, H., Khan, M.A. and Sharif, M. (2012) Effect of Planting Density on Phenology, Growth and Yield of Maize (Zea mays L.). Pakistan Journal of Botany, 44, 691-696.

[19] Olakojo, S.A., Ogundodede, B.A. and Kogbe, J.O.S. (1993) Evaluation of Maize (Zea mays) Top Crosses in a Rainforest Location. Bioresearch Communications, 11, 141146.

[20] Enujeke, E.C. (2013b) Effects of Variety and Spacing on Yield Indices of Open-Pollinated Maize in Asaba Area of Delta State. Sustainable Agriculture Research, 2, 1-11. https://doi.org/10.5539/sar.v2n4p1

[21] Maqsood, M., Abid, A.M., Iqbal, A. and Hussain, M.I. (2001) Effect of Variable Rate of Nitrogen and Phosphorus on Growth and Yield of Maize (Golden). Journal of Biological Sciences, 1, 19-20. https://doi.org/10.3923/jbs.2001.19.20

[22] Obi, I.U. (1999) Effect of Nitrogen Rates and Intra-Row Spacing on Local Maize (Zea mays) in Southern Guinea Savannah Zone of Nigeria. Journal of Sustainable Agriculture and Environment, 5, 147-152.

[23] Nasir, M. (2000) Effects of Different Plant Population on Yield and Yield Components of Different Maize Varieties. MSc Thesis, Department of Agronomy, KPK Agricultural University, Peshawar.

[24] Enujeke, E.C. (2013a) Effects of Variety and Spacing on Growth Characters of Hybrid Maize. Asian Journal of Agriculture and Rural Development, 3, 296-310. http://www.aessweb.com/pdf-files/6-234-AJARD-3(5)2013-296-310.pdf

[25] Akbar, H., Khan, P.A., Saeed, Z.H. and Munir, M. (1996) Biomass, Grain Yield and Harvest Index as Criteria for Comparing Corn Types at Different Nitrogen Levels and Planting Densities. Sarhad Journal of Agriculture, 12, 117-121.

[26] Genet, G. (2013) Effect of Dry Sowing, Seed Hydro Priming and Varieties of Maize in Hamelmalo. MSc Thesis, Hamelmalo Agricultural College, Keren.

[27] Cooper, P.J.M., Keatinge, J.D.H. and Kukula, S. (1989) Influence the Environment on the Management and Productivity of Cereals on Vertisol at Indives, Syria. In: Burford, J.R. and Sahrawat, K.L., Eds., Management of Vertisols for Improved Agriculture Development, ICRISAT, Hyderabad, 195-211. 
Submit or recommend next manuscript to SCIRP and we will provide best service for you:

Accepting pre-submission inquiries through Email, Facebook, LinkedIn, Twitter, etc. A wide selection of journals (inclusive of 9 subjects, more than 200 journals)

Providing 24-hour high-quality service

User-friendly online submission system

Fair and swift peer-review system

Efficient typesetting and proofreading procedure

Display of the result of downloads and visits, as well as the number of cited articles Maximum dissemination of your research work

Submit your manuscript at: http://papersubmission.scirp.org/

Or contact ajps@scirp.org 